\title{
Uitdagingen voor het ondernemingsrecht; op weg naar een echt ondernemingsrecht?
}

\author{
Prof. mr. L. Timmerman *
}

\begin{abstract}
De auteur zet uiteen hoe de verhouding tussen onderneming en vennootschap zich vanaf 1900 beeft ontwikkeld. De auteur verwacht dat de invloed van de politiek op de onderneming en vennootschap in de komende jaren zal toenemen. Aan het slot van zijn beschouwing maakt de auteur een paar opmerkingen over de invloed van digitalisering op het vennootschapsrecht.
\end{abstract}

'The future is unknowable, but the past should give us hope.'

\section{Inleiding}

In 1968 begon ik met de rechtenstudie in Rotterdam. Ik werd enthousiast voor het ondernemingsrecht toen ik student-assistent was van prof. Sanders - een aardige, genereuze man, die 100 jaar is geworden. Toen ik solliciteerde, bleek ik de enige die belangstelling voor die functie had. Het waren andere tijden. Pas na 1968 heeft het ondernemingsrecht een grote vlucht genomen. Het verdrong andere onderdelen van het handelsrecht, zoals het vervoer- en zeerecht. Ondernemingen zijn in ons maatschappelijk bestel in de loop van de jaren dominanter geworden. Het werd duidelijk dat ondernemingsrecht invloed heeft op de organisatie van ondernemingen en van belang is voor de inrichting van de maatschappij. Bedenk ook dat mensen ertoe doen. Nederland had het geluk van uitstekende beoefenaren van het ondernemingsrecht, zoals prof. Van der Grinten en prof. Maeijer. Zij schreven belangrijke boeken, organiseerden congressen en zetten zich in voor verbetering van de vennootschapswetgeving. ${ }^{2}$ Hiervan heeft het Nederlandse ondernemingsrecht profijt gehad.

\footnotetext{
Prof. mr. L. Timmerman is hoogleraar ondernemingsrecht, in het bijzonder zijn historische ontwikkeling, aan de Erasmus Universiteit Rotterdam. Tekst van een niet uitgesproken oratie bij het aanvaarden van het vijfjarige honoraire hoogleraarschap ondernemingsrecht, in het bijzonder zijn historische ontwikkeling, aan de Erasmus Universiteit Rotterdam. Ik ben de Erasmus Universiteit dankbaar voor het voorrecht van dit hoogleraarschap (op mijn gevorderde leeftijd van 70 jaar). Een eerdere versie van dit betoog hield de auteur op 13 februari 2020 op een bijeenkomst georganiseerd door het Rotterdamse advocatenkantoor Windt Legrand Leeuwenburgh.

1. Uitspraak toegeschreven aan Winston Churchill.

2. Zie hierover: L. Timmerman, Nijmeegs vennootschapsrecht (naar aanleiding van het vijftigjarig bestaan van het Van der Heijden Instituut), in: 50 jaar Van der Heijden Instituut 1966-2016 (VDHI nr. 148), Deventer: Wolters Kluwer 2017, p. 9-15.
}

Om toekomstige uitdagingen op het spoor te komen, moet je - zo denk ik - de weg terug afleggen. We leven in een 'geschichtliche Zeit'. ${ }^{3}$ Ons handelen is historisch bepaald. Je moet een idee hebben waar we met het huidige vennootschapsrecht staan om iets zinnigs over toekomstige uitdagingen te kunnen zeggen. Als je over de toekomst wilt schrijven, moet je weten: 'What is going on here?'4 Daarom besteed ik aandacht aan de geschiedenis van het Nederlandse ondernemingsrecht vanaf 1900 en daarna kijk ik vooruit.

\section{Uitgangspunten}

Als je greep op de geschiedenis van het recht wilt krijgen, heb je een rode draad nodig waarmee je de vele wetten, rechterlijke uitspraken en gebeurtenissen kunt ordenen. ${ }^{5}$ Anders wordt geschiedenis een niet te vatten hoeveelheid feiten. Bij het overdenken van de Werdegang van ons vennootschapsrecht is de rol van het begrip onderneming in het vennootschapsrecht mij gaan fascineren. Ik wil door de lens van de onderneming naar het vennootschapsrecht kijken.

Uitgangspunt van mijn betoog is dat een onderneming een op winst gerichte organisatie van mensen is die goederen of diensten voortbrengt. Naarmate de tijd voortschrijdt, neemt die organisatie een andere kleur aan. Die verschillende accenten hangen samen met maatschappelijke en economische ontwikkelingen die zich in de loop van de tijd voordoen. Een andere vooropstelling is dat vennootschap en onderneming elkaar beïnvloeden. Regels van vennootschapsrecht bepalen voor een deel hoe de door de vennootschap gedreven onderneming functioneert. Denk aan een aandeelhoudersvergadering die besluit tot een grote winstuitkering. Zo'n uitkering kan de vooruitzichten van de onderneming beperken. De onderneming is in zo'n geval de gevangene van de vennoot-

3. Zie over dit begrip: P. de Rooy, Alles! En wel nu! Een geschiedenis van de jaren zestig, Amsterdam: Wereldbibliotheek 2020, p. 148.

4. Zie hierover uitvoerig: J. Kay \& M. King, Radical uncertainty. Decisionmaking for an unknowable future, Londen: The Bridge Street Press 2020.

5. Zie voor een eerdere poging iets te vertellen over de geschiedenis van het ondernemingsrecht: L. Timmerman, Het Nederlandse vennootschapsrecht tussen 1918 en 2018, enkele schetsmatige opmerkingen, in: 100 jaar handelsrecht. Over heden, toekomst en verleden (Preadviezen Vereeniging Handelsrecht), Zutphen: Uitgeverij Paris 2018, p. 61-100. 


\section{Maandblad \\ Ondernemingsrecht}

schap. De vennootschap kan op haar beurt geraakt worden door gebeurtenissen die in de onderneming plaatsvinden, bijvoorbeeld ingeval de ondernemingsleiding een verkeerde investering doet. Hierdoor kan de vennootschap financieel nadeel oplopen of zelfs failliet gaan.

Een onderneming is actief op diverse markten, zoals de kapitaalmarkt, arbeidsmarkt en producten- of dienstenmarkt. Die markten hebben invloed op de inrichting en het functioneren van ondernemingen. Denk aan het streven naar efficiency teneinde een bepaalde marktpositie te veroveren en de wens van de kapitaalmarkt tot uitbreiding van aandeelhoudersrechten. En er is nog een punt: het vennootschapsrecht dient buigzaam en pragmatisch ${ }^{6}$ te zijn, indien je dit wilt richten op de realiteit van de onderneming. Het dient zich immers aan de veranderende werkelijkheid van de onderneming aan te passen. Bij zo'n benadering passen beweeglijke vennootschapsrechtelijke normen. ${ }^{7}$ Het denken vanuit de onderneming impliceert een open manier van rechtsvinding.

De verbondenheid van vennootschap en onderneming komt tot uitdrukking in de rechtspraak van de Hoge Raad. In de Cancun-beschikking overwoog de Hoge Raad dat het bestuur van de vennootschap het vennootschappelijk belang dient te bevorderen. Dit vennootschappelijk belang wordt volgens de Hoge Raad in de regel bepaald door het bestendige succes van de door de vennootschap gedreven onderneming 8 Voor de vennootschap is de onderneming, als het goed met haar gaat, de kip met de gouden eieren.

\section{Het tijdperk van de opkomst van ondernemingen} (1880-1940)

Hoe heeft de onderneming het vennootschapsrecht beïnvloed? Ik onderscheid vier tijdperken. De eerste fase vangt met het einde van de negentiende eeuw aan. Dat is het tijdperk van de opkomst van ondernemingen. Veel ondernemingen die het economische leven na 1945 domineren, zijn tussen 1880 en 1920 opgericht. ${ }^{9}$ Ik noem de grote vier van het Nederlandse bedrijfsleven: Shell, Philips, Enka, waaruit Akzo is gevormd, en Van den Bergh en Jurgens, waaruit Unilever is ontstaan. Rond 1900 worden Albert Heijn en DSM opgericht. In 1918 werd Hoogovens gestart, een jaar later de KLM. Deze ondernemingen kozen voor de rechtsvorm van een naamloze vennootschap met rechtspersoonlijkheid en beperkte aansprakelijkheid.

6. Ik ben een voorstander van zo'n pragmatische benadering: L. Timmerman, Verbindend vennootschapsrecht, variatie op een thema, in: Verbindend recht (Feestbundel Krijn Haak), Deventer: Kluwer 2012, p. 511-524 en L. Timmerman, Pragmatisch denken over afgeleide schade, WPNR 2013, afl. 6962, p. 115-118.

7. Zie over open normen in het ondernemingsrecht: P. van Schilfgaarde, De redelijkheid en billijkheid in het ondernemingsrecht (IVOR nr. 100), Deventer: Wolters Kluwer 2016.

8. HR 4 april 2014, ECLI:NL:HR:2014:797, NJ 2014/286.

9. J. Luiten van Zanden, Een klein land in de 20e eeuw, economische geschiedenis van Nederland 1914-1995, Utrecht: Het Spectrum 1997, p. 49.
Aan het eind van de negentiende eeuw was er in Nederland sprake van een tweede gouden eeuw. Niet alleen vonden de hierboven genoemde start-ups plaats, maar er werden ook nog altijd markante gebouwen, zoals het Rijksmuseum, het Concertgebouw, de Beurs van Berlage en het Scheepvaarthuis, neergezet. In 1909 werd de eerste Elfstedentocht georganiseerd. ${ }^{10}$ Niet onvermeld mag blijven dat in 1913 op instigatie van het Rotterdamse bedrijfsleven de Nederlandsche Handels-Hoogeschool - de voorganger van de Erasmus Universiteit Rotterdam - werd opgericht.

De toenmalige economische bloei was onder andere het gevolg van een bewust gevoerde politiek van vrijhandel. Van die vrijhandel profiteerden de havens van Rotterdam en Amsterdam en de gehele Nederlandse samenleving. ${ }^{11}$ Nederland wordt vanaf dan een open economie, die verbonden is met de wereldeconomie en waarvoor een zekere mate van veranderingsgezindheid kenmerkend is. ${ }^{12}$

En: naamloze vennootschappen worden juridisch en maatschappelijk belangrijker, omdat ondernemingen aan belang winnen. De wettelijke regeling van de naamloze vennootschap van 1838 telde 21 artikelen. Deze regeling was een rommelpot en niet in overeenstemming met het toenemend belang van naamloze vennootschappen. Veelzeggend is dat personenvennootschappen in de wet uitvoeriger (en beter) waren geregeld dan de naamloze vennootschap. De personenvennootschappen werden echter langzaam maar zeker in maatschappelijk belang overvleugeld door de naamloze vennootschap. Prof. Molengraaff - een beroemde beoefenaar van het handelsrecht die tussen 1880 en 1930 actief was - zei in 1917 over de NVregeling:

'Het beste (...) is wel dat deze regeling zo gebrekkig is en vol leemten is dat zij eigenlijk een regeling niet mag heten.' ${ }^{\prime 3}$

In die tijd was het Nederlandse vennootschapsrecht nog niet sterk ontwikkeld. Omdat het belang van ondernemingen toenam, moest vooral de naamloze vennootschap een uitgebreidere en betere regeling in de wet krijgen. Dat gebeurde in 1928. De Wet van $1928^{14}$ is nog steeds de basis van het huidige NV- en BV-recht en vulde een gat op. Die wet was voortreffelijk ${ }^{15}$ en legde een aantal principes vast, zoals aansprakelijkheid van een bestuurder jegens de vennootschap, openbaarheid van inrichting van de vennootschap en het

10. Zie over dit tijdperk: R.L. Schuursma, Jaren van opgang: Nederland 1900-1930, Amsterdam: Balans 2000.

11. Zie hierover: Joh. de Vries, De Nederlandse economie tijdens de 20ste eeuw, een verkenning van het meest kenmerkende (4de druk), Bussum: Fibula-Van Dishoeck 1983, p. 11.

12. De Vries 1983, p. 41-42.

13. W.P.L.A. Molengraaff, Een terugblik, in: Molengraaff bundel, Zwolle: Tjeenk Willink 1978, p. 81.

14. De wet van 2 juli 1928 , Stb. 216

15. Zie het bijzondere nummer van de Naamlooze Vennootschap, jaargang 1953, p. 181-244, dat verscheen ter gelegenheid van het 25-jarig jubileum van de Wet van 1928. 
begin van het enquêterecht. Tegelijkertijd was de wet ook flexibel, omdat deze niet in details trad. ${ }^{16}$ Aan de totstandkoming van een goede, nieuwe dogmatiek voor het vennootschapsrecht heeft de Wet van 1928 bijgedragen met een goed doordachte opzet en scherp geformuleerde wetsartikelen.

Niet alleen de wetgever van 1928 heeft de ontwikkeling van de vennootschapsrechtelijke dogmatiek bevorderd, maar ook de Hoge Raad heeft daaraan in die tijd bijgedragen. Zo heeft de Hoge Raad arresten gewezen over het afgescheiden vermogen van de vennootschap onder firma, ${ }^{17}$ over de rechtspersoonlijkheid van de naamloze vennootschap, ${ }^{18}$ het gebruik van stromannen op de aandeelhoudersvergadering (die hebben geen stemrecht), ${ }^{19}$ de reikwijdte van decharge (die betreft slechts feiten die aan de aandeelhouders bekend zijn), ${ }^{20}$ de verruiming van de persoonlijke aansprakelijkheid van de bestuurders jegens benadeelde derden (die werd voorheen slechts in zeer uitzonderlijke gevallen mogelijk geacht $)^{21}$ en het beginsel dat de aandeelhouders zich aan de door hen zelf vastgestelde statuten dienen te houden ${ }^{22}$ (denk ook aan het latere Forumbankarrest $\left.^{23}\right)$. De vennootschap krijgt als het ware een constitutioneel karakter. ${ }^{24}$ Het arrest uit 1938 (Eugen Mehler) is een van de uitspraken die het begin van de zogeheten institutionele opvatting markeert. ${ }^{25}$ Alle hierboven genoemde arresten spreken inmiddels vanzelf, maar zij waren in de tijd waarin zij werden gewezen grote vernieuwingen.

In de periode van 1900 tot 1940 was Nederland op weg een modern land te worden. Niet alleen de Wet van 1928 werd van kracht, maar ook de nieuwe Wet op de arbeidsovereenkomst, die vele jaren de basis voor de beoefening van

16. Zie over die wet: H.J.M.N. Honée, De ontwikkeling van het vennootschapsrecht, in: Harry Honée-bundel (IVOR nr. 84), Deventer: Kluwer 2011, p. 17-26 en L.E. Visser, De naamlooze vennootschap volgens de wet van 2 juli 1928, Stb. no 2016 (Beginselen van handelsrecht volgens de Nederlandsche wet, supplement op deel III), Den Haag: Belinfante 1929.

17. HR 26 november 1897, W. 7047 .

18. HR 18 januari 1901, W. 7553.

19. HR 4 juni 1920, ECLI:NL:HR:1920:AG1779, NJ 1920, p. 712 . Over dit arrest schreef Van der Grinten nog een opstel, Stromannen en kunststro, opgenomen in: Verspreide geschriften van W.C.L. van der Grinten (VDHI nr. 77), Deventer: Kluwer 2004, p. 463-473.

20. HR 17 juni 1921, ECLI:NL:HR:1921:AG1780, NJ 1921, p. 737.

21. HR 25 november 1927, ECLI:NL:HR:1927:BG9436, NJ 1928, p. 364 Zie over de bestuurdersaansprakelijkheid voor 1927: J.M. de Jongh, Bestuurdersaansprakelijkheid 1838-1928: individueel of hoofdelijk?, in: JB: opstellen aangeboden aan J.B. Huizink, Deventer: Wolters Kluwer 2019, p. 229-248.

22. HR 8 april 1938, ECLI:NL:HR:1938:236, NJ 1938/1076.

23. HR 21 januari 1955, ECLI:NL:HR:1955:AG2033, NJ 1959/43. Zie over dit arrest verhelderend: F.G.K. Overkleeft, De positie van aandeelhouders in beursvennootschappen: een analyse van recht, gebeurtenissen en ideeën (diss. Rotterdam; IVOR nr. 103), Deventer: Wolters Kluwer 2017, p. 51-56.

24. Zie S. Bottomley, The constitutional corporation: Rethinking corporate governance, Aldershot: Ashgate Publishing 2007.

25. Zie over het begin van de institutionele opvatting: J.M. de Jongh, Tussen societas en universitas. De beursvennootschap en haar aandeelhouders in historisch perspectief (diss. Rotterdam; IVOR nr. 94), Rotterdam: Erasmus Universiteit Rotterdam 2014, p. 322-366. het Nederlandse arbeidsrecht was, kwam in 1907 tot stand. ${ }^{26}$ Rietveld ontwierp in die periode zijn rood-blauwe stoel, Mondriaan maakte zijn abstracte schilderijen en Zwart bedacht de functionele Bruynzeel-keuken, waarin de stijl van Rietveld en Mondriaan te herkennen was. Karel Appel startte zijn loopbaan met wilde, kleurige schilderijen. Prof. Sanders had enkele van die vroege schilderijen van Appel in zijn bezit. Hij had Appel in het vooroorlogse Amsterdam, waar hij toen advocaat was, leren kennen. ${ }^{27}$ Het bedrijfsleven werd gemoderniseerd met bijvoorbeeld de invoering van de lopende band. Er ontstond een nieuw soort onderneming met een machtig professioneel managementapparaat. Het managerial capitalism krijgt vorm. ${ }^{28}$ Het leiden van een onderneming werd een vak apart. De functie van manager ontstaat. ${ }^{29}$

De verbetering van de vennootschapsrechtelijke dogmatiek is onderdeel van dit moderniseringsproces. Deze was onder andere te danken aan de genoemde Molengraaff ${ }^{30}$ en Visser, een raadsheer uit de Hoge Raad die een van de opstellers van de Wet van 1928 was. ${ }^{31}$ Visser schreef een nog steeds lezenswaardig, helder commentaar op die wet. In dat commentaar wordt de vernieuwde dogmatiek beknopt uiteengezet. ${ }^{32}$ Aardig is te vermelden dat deze beide bijzondere juristen een belangrijke bijdrage hebben geleverd aan de modernisering van het onrechtmatigedaadsrecht. Molengraaff schreef in 1887 een verhandeling waarin hij verdedigde dat niet slechts hij die een wettelijk voorschrift overtreedt onrechtmatig handelt, maar dat dit ook moet gelden voor degene die regels van meer zedelijke aard en voorzichtigheid overtreedt. ${ }^{33}$ Visser was een van de raadsheren die het arrest Lindenbaum/Cohen ${ }^{34}$ wees. In dat arrest werd de ruime visie op artikel $1401 \mathrm{BW}^{35}$ van Molengraaff aanvaard. Het arrest Lindenbaum/Cohen veranderde het Nederlandse privaatrecht grondig en blijvend.

\section{De fase van de sociale onderneming (1945-1980)}

Nederland beleefde in de jaren dertig van de vorige eeuw een economische crisis. Er ontstaat in Nederland (onder druk van

26. Wet van 13 juli 1907, Stb. 193. Zie C. Jansen \& C. Loonstra, Opstellen over de historische ontwikkeling van het arbeidsrecht, Den Haag: Boom Juridische uitgevers 2013, p. 73-84 over het destijds vernieuwende karakter van deze wet.

27. P. Sanders, Herinneringen, Amsterdam: SUN 2009, p. 26-28 en 110.

28. Luiten van Zanden 1997, p. 67-76. Zie hierover uitvoerig: B. Cheffins, The public company transformed, New York: Oxford University Press 2019, p. 39-100.

29. Zie hierover R. Hartmans, Schaduwjaren, de jaren dertig in Nederland, Utrecht: Omniboek 2018, p. 147-184.

30. Veel van de door Molengraaff bepleite vernieuwingen zijn te vinden in de elkaar opvolgende drukken van zijn Leidraad bij de beoefening van het Nederlandsche handelsrecht.

31. Visser werd later president van de Hoge Raad.

32. Visser 1929

33. Zie W.P.L.A. Molengraaff, De 'oneerlijke concurrentie' voor het forum van den Nederlandschen rechter, tevens een bijdrage tot de uitlegging van art. 1401 B.W. en van de Wet op de handels- en fabrieksmerken, in: Molengraaff bundel, Zwolle: Tjeenk Willink 1978, p. 115.

34. HR 31 januari 1919, W. 10365.

35. Dit artikel regelde destijds de onrechtmatige daad. 


\section{Maandblad}

Ondernemingsrecht

die crisis?) belangstelling voor gemeenschapsdenken. ${ }^{36}$ Men zoekt naar nieuwe eenheden met een eigen identiteit en belang. Een voorbeeld van zo'n gemeenschap is de onderneming. Er ontstaat interesse voor de gedachte van medezeggenschap van werknemers. ${ }^{37}$ De onderneming krijgt een sociale dimensie. De fase van de sociale onderneming vangt aan.

Het beëindigen van de Tweede Wereldoorlog versterkt het sociaal geïnspireerde denken. Er heerste toentertijd in Nederland een saamhorigheidsgevoel: 'We moeten het samen doen.' Illustratief is een boek dat prof. Romme - een katholiek politicus - in 1946 publiceerde: De onderneming als gemeenschap in het recht ${ }^{38} \mathrm{Hij}$ verdedigde dat de onderneming een gemeenschap is waarin arbeid, kapitaal en leiding verenigd zijn met een eigen juridisch statuut. Romme wilde de achterstelling van de werkenden opheffen en de onderneming losmaken van het vennootschapsrecht, dat door zijn aard aan de kapitaalverschaffers een preponderante positie geeft. Romme wilde de onderneming bevrijden uit de kooi van de vennootschap. Later (in de jaren zestig van de vorige eeuw) ontstaat een in Nederland breed beleden behoefte aan authenticiteit en zelfontplooiing ('gewoon jezelf kunnen zijn'). ${ }^{39}$ Het gezag van de ondernemingsleiding komt onder druk te staan.

Dit type ideeën is de basis voor de Wet op de ondernemingsraden (WOR; eerste versie 1950), de structuurregeling met vennootschapsrechtelijke inspraak voor de ondernemingsraad (eerste versie 1971), het enquêterecht met de mogelijkheid van een inbreng door vakbonden (eerste versie 1970) en de SERfusiegedragsregels met een rol voor de vakbonden bij fusies (eerste versie 1970). Tot ongeveer het midden van de jaren zeventig van de vorige eeuw staan de onderneming en het Nederlandse vennootschapsrecht in het teken van de medezeggenschap van werknemers (ook in Duitsland; over het idee van de Mitbestimmung werden daar toen bibliotheken vol geschreven). ${ }^{40}$ Men wilde de werknemers in de onderneming en de vennootschap integreren. Ik kan mij dat goed herinneren. ${ }^{41}$

36. Ik verwijs o.a. naar C.M.O. van Nispen tot Sevenaer, De rechtspersoon, een studie over het wezen der rechtspersoon en deszelfs beteekenis voor staats- en privaatrecht, Haarlem: Tjeenk Willink 1936, p. 11-20.

37. Zie hierover de vroege studie van G. van den Bergh, De medezeggenschap der arbeiders in de particuliere onderneming (diss. Amsterdam UvA), Amsterdam: Ontwikkeling 1924.

38. Zie voor een kritische bespreking van de ideeën van Romme: W.C.L. van der Grinten, De structuur der naamloze vennootschap (oratie Tilburg), 1951, opgenomen in Verspreide geschriften van W.C.L. van der Grinten (VDHI nr. 77), Deventer: Kluwer 2004, p. 323-339. Zie voor een Duits boek met ideeën die vergelijkbaar zijn met die van Romme: Th. Raiser, Unternehmen als Organisation, Berlijn: De Gruyter 1969. Ik merk nog op dat Van der Grinten een tegenstander was van het benaderen van de vennootschap vanuit het gezichtspunt van de onderneming. Voor mij is dit een te dogmatische houding. Ik wil de juridische figuur van de vennootschap nu juist confronteren met de realiteit van de onderneming.

39. De Rooy 2020, p. 150.

40. Zie voor een exemplarische studie: H.J.M.N. Honée, Concernrecht en medezeggenschapsregelingen (diss. Nijmegen), Deventer: Kluwer 1981.

41. Zie L. Timmerman, Medezeggenschap van werknemers en multinationale ondernemingen (diss. Utrecht), Deventer: Kluwer 1988.

\section{De periode van de bijna exclusief economische onderneming (1980-2015)}

In de jaren zeventig van de vorige eeuw volgt een kentering. Een derde periode vangt aan. Dat is de fase van wat ik noem de bijna exclusief economische onderneming. Dit tijdperk treedt in, omdat de westerse economieën in stagnatie en bureaucratie waren vastgelopen. Er was te weinig dynamiek. Het ondernemerschap komt onder druk te staan. ${ }^{42}$

Voor de rechtspositie van een werknemer in een onderneming waren dienstjaren en senioriteit en niet bekwaamheden van doorslaggevend belang. De inflatie was in 1975 9,6\%. Er waren begrotingstekorten van meer dan $10 \%$ en er was grote werkloosheid (in 1980 waren er 1 miljoen werklozen). In 1981 was de economische groei in Nederland negatief. Daaroverheen kwam ook nog eens de oliecrisis. Destijds spraakmakende ondernemingen, zoals RSV en OGEM, gingen met veel geraas ten onder. Die grote faillissementen gaven aanleiding tot juridische verhandelingen met nieuwe onderwerpen, zoals over de sterfhuisconstructie en de werking van hoofdelijke aansprakelijkheid en regres bij concerns in financiële moeilijkheden. ${ }^{43}$

Er moest iets gebeuren om dit te veranderen. Rechtse economen, zoals de Amerikaan Friedmann, en rechtse politici, zoals de Amerikaanse president Reagan en de Engelse premier Thatcher, zetten de toon. Nederland neemt in een aantal elkaar opvolgende kabinetten in gematigde vorm het Amerikaanse en Engelse beleid over. De invloed van het Anglo-Amerikaanse denken neemt toe. Amerikaans en Engels vennootschapsrecht worden onze inspiratiebron. Daarvoor was Nederland op Duitsland en Frankrijk gericht. We slaan met onze economie een nieuwe weg in. De staat treedt terug. Het marktdenken gaat de inrichting van de maatschappij bepalen. De voltooiing van de Europese Single Market onder leiding van de Engelse Lord Cockfield verstevigt vanaf 1986 het marktdenken .

Er wordt (fors) bezuinigd op het sociale vangnet, gedereguleerd, geprivatiseerd en verzelfstandigd. Centrale waarden worden vrijheid (van ondernemen) en concurrentie. ${ }^{44}$ Mensen worden beoordeeld op wat zij individueel hebben bereikt. Er vindt een decline of the public ${ }^{45}$ plaats. Een typerende uitspraak uit die tijd luidt: 'There's no such thing as society. There are individual men and women and there are families' (Margaret

42. Zie hierover J. van Gerwen \& F. de Groot, Ondernemers in Nederland. Variaties in ondernemen, Amsterdam: Boom 2008, p.144-174, en zie voor een boek van een tijdgenoot die waarschuwde voor het ondergraven van ondernemerschap: J.R.M. van den Brink, Zoeken naar een 'heilstaat': opbouw, neergang en perspectief van de Nederlandse welvaartstaat, Amsterdam: Elsevier 1984.

43. Zie bijv. W.J. Slagter, De sterfhuisconstructie, Ondernemingsrecht 1983, p. 25-31. Zie ook de recente studie van C.H.A. van Oostrum, Regres bij concernfinanciering (VDHI nr. 156), Deventer: Wolters Kluwer 2019, waarin een overzicht te vinden is van de problematiek.

44. P. de Rooy, Ons stipje op de waereldkaart. De politieke cultuur van modern Nederland, Amsterdam: Wereldbibliotheek 2014, p. 281.

45. Zie D. Marquand, Decline of the public: The hollowing out of citizenship, Maiden, MA: Polity Press 2004. 
Thatcher). ${ }^{46}$ Het gemeenschapsdenken raakt in diskrediet. De institutionele kijk op de vennootschap komt onder druk te staan.

Kapitaalmarkten worden door het dereguleringsbeleid wereldwijd vrijer gemaakt. Kapitaal beweegt zich gemakkelijker over de wereld. Het krijgt meer keuzemogelijkheden en wordt machtiger. De meerderheid van aandelen in Nederlandse beursvennootschappen komt in handen van deskundige, veelal buitenlandse investeerders, de zogeheten institutionele beleggers. ${ }^{47}$ De Nederlandse wetgever maakt het vennootschapsrecht meer aandeelhoudersgericht. ${ }^{48}$ Ondernemingen leggen minder nadruk op hun sociale dimensie en krijgen een meer exclusief economische kleur. ${ }^{49} \mathrm{Zij}$ raken door hun gerichtheid op kapitaalverschaffers en kapitaalmarkten ontworteld, dat wil zeggen: zij komen losser te staan van de gemeenschap waaruit zij voortkomen..$^{50}$ De positie van de vakbonden als tegenmacht verzwakt. ${ }^{51}$

Ik noem een paar kenmerkende ontwikkelingen:

a. Het winststreven ten bate van aandeelhouders en in het verlengde hiervan de maximalisatie van aandeelhouderswaarde worden onder druk van de kapitaalmarkten dominant. Dit uit zich onder andere in hoge dividenduitkeringen en grootschalige inkoop van aandelen. ${ }^{52}$ Een aantal ondernemingen wordt door hun aandeelhouders als een soort financiële machine behandeld. $\mathrm{Zij}$ worden via ingewikkelde constructies met vennootschappen met rentedragende leningen volgehangen om de eigen, eerder plaatsgevonden overname te financieren (denk aan de al jaren kwakkelende HEMA, waarbij zo'n constructie is toegepast). Deze leningen drukken de winst van de betrokken ondernemingen, waardoor hun voortbestaan voortdurend aan een zijden draadje hangt. Niet-strategische onderdelen van de onderneming worden buiten de

46. Mevrouw Thatcher heeft dit gezegd in een interview for Woman's Own van 23 september 1987. Zie voor een boek waarin de teloorgang van het gemeenschapsdenken wordt beschreven en voor een terugkeer ervan wordt gepleit: R. Rajan, The third pillar: The revival of community in a polarised world, Londen: William Collins 2019.

47. Institutionele beleggers houden zo gemiddeld $75 \%$ in Nederlandse beursvennootschappen. Zie over het veranderend aandeelhoudersbestand: Overkleeft 2017, p. 105-113 en 355-364.

48. Zie bijv. het in 2004 ingevoerde art. 2:107a BW (goedkeuring van belangrijke transacties door de aandeelhoudersvergadering) en het uitgeklede structuurregime waarin aandeelhouders meer bevoegdheden krijgen.

49. Zie voor een fraaie kritiek op dit type vennootschapsrecht: A.A. Singer, The form of the firm. A normative political theory of the corporation, Oxford: Oxford University Press 2019. Zijn kritiek komt erop neer dat deze manier van beoefening van het vennootschapsrecht een contractuele benadering is en daardoor een ethische grondslag mist.

50. Zie hierover de fraaie studie van A.W.A. Boot, De ontwortelde onderneming. Ondernemingen overgeleverd aan financiers?, Assen: Koninklijke Van Gorcum 2009.

51. Het ledenaantal van de vakbonden daalt in deze periode van $35 \%$ naar $24 \%$ van de werknemers. Vooral onder jongere werknemers is de organisatiegraad laag (10\%).

52. Zie voor cijfers hierover: L. Timmerman, De toekomst van corporate governance (te publiceren in het Van der Heijden-congresboek over corporate governance). deur gezet. Deze gang van zaken doet zich vooral voor als vennootschappen van de beurs worden gehaald en de aandelen in handen komen van private equity-fondsen. ${ }^{53}$

b. De belangen van aandeelhouders en bestuurders worden aan elkaar geknoopt door prestatiegebonden bonussen en opties op aandelen. Bestuurders raken hierdoor meer aandeelhouders-minded. Werknemers worden een kostenpost waarop wordt bezuinigd, onder andere door robotisering en het verplaatsen van werk naar Oost-Europa en Azië. De overheid laat toe dat werkgevers arbeid goedkoper maken door het faciliteren van allerlei vormen van flexibele arbeidsconstructies. ${ }^{54}$ Hierdoor kon de winstgevendheid van veel ondernemingen toenemen. Als gevolg van dit type beleid wordt de onderneming een minder duurzaam, losser samenwerkingsverband met minder loyaliteit van de werkenden.

c. De economische benadering van de onderneming verlangt een vennootschapsrecht dat flexibel is en geen stain-de-weg is voor de winstgevendheid van ondernemingen. Hierin past de belangrijke flexibilisering van het BVrecht. ${ }^{55}$ Die flexibilisering pakt gunstig uit voor aandeelhouders, omdat zij in een BV meer vrijheid van handelen krijgen. In dit patroon passen ook de nieuwe wettelijke regels voor grensoverschrijdende juridische fusies ${ }^{56}$ en dienen de Europese ideeën voor grensoverschrijdende splitsingen en omzettingen te worden begrepen. ${ }^{57}$ Deze vennootschapsrechtelijke technieken vergemakkelijken het verrichten van economisch wenselijke transacties.

d. Vanuit financiële markten worden eisen gesteld aan de transparantie en inrichting van beursvennootschappen. ${ }^{58}$ Deze problematiek staat bekend als corporate governance en heeft geleid tot diverse gedragscodes. Deze beogen aanvankelijk versterking van aandeelhoudersrechten en verbetering van het functioneren van de raad van commissarissen $^{59}$ (denk aan de Veertig Aanbevelingen

53. Zie voor een kras, goed gedocumenteerd voorbeeld van het optreden van een private equity-partij: Hof Amsterdam (OK) 10 januari 2008, ECLI:NL:GHAMS:2008:BC1657, JOR 2008/39 (PCM), en voor een voorbeeld van een veel toegepaste financieringsconstructie bij een aandelenovername die voor aandeelhouders meestal telkens gunstig uitpakt: J.A. de Vries \& R.J. de Weijs, Corporate finance en ondernemingswaardering, in: R.J. de Weijs (red.), Grenzen aan financieringsvrijheid, Deventer: Wolters Kluwer 2020, p. 64-71. Vgl. ook Hof Amsterdam (OK) 10 december 2019, ECLI:NL:GHAMS:2019:4359, Ondernemingsrecht 2020/48. In deze beschikking wijst de Ondernemingskamer een enquête toe inzake Estro.

54. Zie hierover het kritische rapport van de commissie-Borstlap 'In wat voor land willen we werken?' en het rapport van de WWR 'Het betere werk'. In Nederland hebben vier van de tien werkenden een flexibele arbeidsrelatie of zijn zzp'er.

55. Wet van 18 juni 2012, Stb. 2012, 299 en 300.

56. Wet van 6 juni 2008, Stb. 2008, 260.

57. Zie art. 86bis e.v. (grensoverschrijdende omzetting) en art. 160bis e.v. (grensoverschrijdende splitsing) van Richtlijn (EU) 2019/2121 van 27 november 2019, PbEU 2019, L 321/1.

58. Zie hierover uitvoerig en genuanceerd: Boot 2009.

59. Het verbeteren van het functioneren van de raad van commissarissen zou ertoe moeten bijdragen dat het bestuur betere, meer rationele besluiten neemt, zie hierover A. de Jong, De ratio van corporate governance (oratie Rotterdam), 2006. 


\section{Maandblad}

Ondernemingsrecht

van de commissie-Peters ${ }^{60}$ en de Code Tabaksblat). In de Corporate Governance Code van 8 december 2016 wordt de koers verlegd. Deze wil dat een onderneming als purpose voor langetermijnwaardecreatie kiest. Ook wijdt de Code een sympathiek principe aan cultuur in de onderneming. In paragraaf 2.5.3 van de Code wordt het bestuur de verplichting opgelegd de cultuur in de vennootschap en de daarmee verbonden onderneming met de ondernemingsraad te bespreken.

Ik teken aan dat in de periode van de bijna exclusief economische onderneming het Nederlandse vennootschapsrecht twee gezichten heeft. De Hoge Raad is niet meegewaaid met de tendens naar een op de aandeelhouders georiënteerd vennootschapsrecht. Hij heeft, zoals we hebben gezien, in zijn Cancun-uitspraak ${ }^{61}$ het vennootschappelijk belang omschreven als het bestendige succes van de door de vennootschap gedreven onderneming. Voor het succes van die onderneming zijn winst en efficiency nodig. De Hoge Raad tempert dit winst- en efficiency-streven door te overwegen dat het succes bestendig dient te zijn (dus geen winststreven op korte termijn) en de op de onderneming en vennootschap betrokken belangen niet onevenredig mogen worden geschaad. Dit brengt mee dat het bestuur gewicht dient toe te kennen aan alle op de vennootschap en de onderneming betrokken belangen (de zogeheten stakeholderbenadering).

De Hoge Raad injecteert in zijn Cancun-beschikking de vennootschap met wat ik zou willen noemen rechtvaardigheidsserum. Vanaf het Doetinchemse IJzergieterij-arrest ${ }^{62}$ via de ABN Amro-zaak ${ }^{63}$ heeft de Hoge Raad de vaste lijn gevolgd van de verplichting voor het bestuur (en de raad van commissarissen) tot het behartigen van een pluraliteit van belangen.

De vraag is hoe effectief de door de Hoge Raad in zijn Cancun-beschikking opgelegde beperkingen op het winststreven in het dagelijks bestaan van een onderneming zijn. Men kan twijfelen aan de effectiviteit van het belangenpluralisme. De (rechterlijke) controle op de naleving van de Cancun-normen is beperkt, onder andere omdat deze vaag zijn, ze veel aan de discretie van het bestuur overlaten en zaken slechts incidenteel aan de rechter worden voorgelegd.

Ik vind het een moeilijk te beantwoorden vraag of Nederlandse beursvennootschappen ondanks de Cancun-beschikking en een aantal Cancun-achtige uitspraken van de Ondernemingskamer ${ }^{64}$ in de harde economische praktijk in

60. Zie over die aanbevelingen: Corporate governance in Nederland 2002, de stand van zaken, een uitgave onder auspiciën van de Nederlandse Corporate Governance Stichting.

61. HR 4 april 2014, ECLI:NL:HR:2014:797, NJ 2014/286. Zie hierover ook Overkleeft 2017, p. 397-419.

62. HR 1 april 1949, ECLI:NL:HR:1949:126, NJ 1949/465.

63. HR 13 juli 2007, ECLI:NL:HR:2007:BA7972, NJ 2007/434.

64. Ik noem in dit verband vooral de AkzoNobel-uitspraak van Hof Amsterdam (OK) 29 mei 2017, ECLI:NL:HR:2017:1965, JOR $2017 / 261$. de periode vanaf 1980 niet sterker geleid worden door het aandeelhoudersmodel dan door het stakeholdermodel. Naar alle waarschijnlijkheid steekt de aandeelhoudersbenadering voor sommige aangelegenheden (beleid inzake dividend, inkoop van aandelen en bonussen) de kop op, en voor andere kwesties (vooral het afweren van een door het bestuur niet-gewenste overname) het stakeholderdenken. Denk bij dit laatste aan de AkzoNobel-uitspraak van de Ondernemingskamer. In zo'n geval ontpopt het belaagde bestuur zich doorgaans als fervent aanhanger van het stakeholderdenken. ${ }^{65}$

Voordat ik aan mijn laatste periode toekom, maak ik nog twee zijstappen. De Hoge Raad heeft in het vennootschapsrecht ruimte gemakkt voor begrippen uit de ondernemingssfeer. Dat gebruik van dergelijke begrippen hoeft niet te betekenen dat het aandeelhoudersbelang het zwaarst weegt. Zo heeft de Hoge Raad in de recente Fugro-beschikking aan het begrip strategie $^{66}$ - hij en de Ondernemingskamer deden dit al eerder ${ }^{67}$ - een plek in het vennootschapsrecht gegeven. ${ }^{68} \mathrm{Het}$ vaststellen van de strategie is - zo besliste de Hoge Raad - een bevoegdheid van het bestuur onder toezicht van de raad van commissarissen. De aandeelhoudersvergadering staat hier in beginsel buiten, tenzij de wet ${ }^{69}$ of de statuten anders bepalen. Verantwoording achteraf over de gevoerde strategie aan de aandeelhoudersvergadering dient wel plaats te vinden. Deze beschikking laat zien dat het bestuur (en de raad van commissarissen) met het ene been in de vennootschap staat (er moet verantwoording aan de aandeelhoudersvergadering worden afgelegd) en met het andere in de onderneming (een strategie wordt in de eerste plaats met het oog op het succes van de onderneming uitgedacht).

Opmerkelijk is ook dat de aandacht voor het economische verschijnsel concern in de wetgeving en rechtspraak intensiveert. Een concern is een onderneming die verschillende vennootschappen overkoepelt. Dat verschijnsel roept vele vragen op, zoals die rond aansprakelijkheid en toerekening van werknemers, gedragingen en kennis. In Nederland bestond vroeg belangstelling voor het concern (waarschijnlijk omdat we al

65. Zie voor een vergelijkbare waarneming: J. Winter, Ontmenselijking van de grote onderneming, Ondernemingsrecht 2019, p. 6. Overigens verdedigt Leo Strine voor het Amerikaanse recht dat invoering van het stakeholdermodel geen zin heeft, omdat de bevoegdheden van de aandeelhouders in een Amerikaanse kapitaalvennootschap te omvangrijk zijn: 'shareholder primacy necessarily flows from the power structure of the corporation', in: Corporate power is corporate purpose I: Evidence from my hometown, Oxford Review of Economic Policy 2017, p. 176.

66. In De rol van vennootschappelijk belang en strategie bij het beschermen van beursvennootschappen, TvOB 2018, p. 15 heb ik een omschrijving van strategie gegeven. Ik heb het daar omschreven als een plan van de ondernemingsleiding om het succes van de onderneming op de lange termijn te bevorderen.

67. Zie eerder o.a. HR 9 juli 2010, ECLI:NL:HR:2010:BM0976, NJ 2010/544 (Asmi).

68. HR 20 april 2018, ECLI:NL:HR:2018:652, NJ 2018/331.

69. Denk bijv. aan art. 2:107a BW. 
lang geleden concerns als Shell kenden ${ }^{70}$ ). Voor het concern worden om recht te doen aan de gecompliceerde realiteit ervan steeds meer bijzondere wettelijke en jurisprudentiële regels bedacht. ${ }^{71}$

\section{En nu: de politieke onderneming (2015 tot heden)}

Recent is het ondernemingsbegrip opnieuw aan het schuiven. De onderneming krijgt een politieke dimensie. Het tijdperk van de politieke onderneming (de vierde fase dus) breekt aan. Deze verschuiving wordt veroorzaakt door onvrede met het functioneren van ondernemingen. Ondernemingen hebben omvangrijke macht, onder andere door effectieve lobby's bij de politiek. Aandeelhouders ontvangen, zoals we hebben gezien, hoge uitkeringen. Er zijn hoge beloningen voor bestuurders. Er bestaat in de maatschappij ergernis over de onevenwichtig verdeelde gevolgen van de kredietcrisis uit 2008. Ondernemingen blijven een hard beleid jegens delen van werkenden voeren, onder andere door een flexibele schil in stand te houden. De aandacht voor de omstandigheid dat markten lang niet altijd goed functioneren, groeit. ${ }^{72}$ Rebecca Henderson vat het voorafgaande fraai samen:

'Too much focus on the public good stifles the entrepreneurial dynamic that is the lifeblood of well-functioning markets. Too much focus on economic freedom leads to the destruction of the social and natural work and the steady degradation of the institutions that hold the market in balance. ${ }^{73}$

Het bijzondere van de vierde fase is dat de regelgevers de onderneming via onder andere het vennootschapsrecht met een soort publieke taken belasten. Een voorbeeld is het bestrijden van klimaatverandering en het bevorderen van duurzaamheid (denk aan de rapportageverplichtingen hierover in het bestuursverslag $^{74}$ en par. 1.1.1 onder vi van de Corporate Governance Code, die het bestuur van een beursvennootschap tot strategisch beleid op het punt van duurzaamheid verplicht). Ook kunnen worden genoemd het bevorderen van diversiteit (denk aan de te verwachten quotaregeling voor de benoeming van commissarissen ${ }^{75}$ en par. 2.1.5 van de Corporate Governance Code, die de vennootschap tot diversiteitsbeleid verplicht), het verplichte bezoldigingsbeleid voor

70. Zie voor een vroege studie over het concern: Shell-jurist D.J. Sannes, De rechtsverhouding van moeder- en dochtermaatschappij (diss. Utrecht), Zutphen: Thieme 1926.

71. Zie voor een boek waarin inzicht in deze vele regels wordt gegeven: S.M. Bartman, A.F.M. Dorresteijn \& M. Olaerts, Van het concern, Deventer: Wolters Kluwer 2016.

72. Zie hierover voor de Verenigde Staten: T. Philippon, The great reversal, how America gave up free markets, Cambridge: Harvard University Press 2019.

73. R. Henderson, Reimagining capitalism. How business can save the world, Londen: Penguin Books 2020, p. 28.

74. Dat is geregeld in art. 2:391 lid 5 BW en het Besluit bekendmaking nietfinanciële informatie, Stb. 2017, 100.

75. Zie hierover het SER-advies 2019/12 'Diversiteit in de top, tijd voor versnelling' en het Voorontwerp modernisering NV-recht en evenwichtiger man/vrouw verhouding (www.internetconsultatie.nl/nvenmv). bestuurders ${ }^{76}$ en het bestrijden van fraude. Bij dit laatste gaat het vooral om het tegengaan van corruptie en het witwassen van drugsgeld. De notaris dient deze kwalijke verschijnselen bij diverse vennootschapsrechtelijke handelingen, zoals de oprichting van een vennootschap, te verhinderen. ${ }^{77}$

Deze nieuwe publieke taken zijn uitdagingen voor ons vennootschapsrecht. De normen voor onderneming en vennootschap worden aangescherpt. Er lijkt weer iets van een bedrijfsgemeenschappelijkheid en samenhorigheid te ontstaan. Er vindt misschien zelfs wel een zekere herworteling van de vennootschap plaats. Als gevolg van de ingrepen van de wetgever komt de onderneming wat losser te staan van het behartigen van het winstbelang van de aandeelhouders. Deze al bestaande tendensen worden waarschijnlijk door de coronacrisis versneld. Het is aannemelijk dat we een periode tegemoetgaan waarin de overheid zich in ruil voor steunverlening aan ondernemingen actiever met vennootschappen gaat bezighouden. Interessant is bijvoorbeeld dat de Europese Centrale Bank het nu al niet toelaat dat financiële instellingen dividenduitkeringen doen.

Hoe zal dit verder gaan? Het is denkbaar dat een onderneming in de komende tijd meer publiekrechtelijke trekken zal krijgen. Aan die mogelijke ontwikkeling besteed ik eerst aandacht. Aan het slot van mijn verhandeling ga ik in op digitalisering als 'game changer' van het vennootschapsrecht. Misschien gaat de digitalisering allerlei plannen met ons vennootschapsrecht overhoopgooien.

\section{Can we be happier?}

Een goede inrichting van de samenleving kan het geluk van ons mensen bevorderen. ${ }^{78}$ Denk aan een stad met fraaie parken. ${ }^{79}$ Een goede gezondheidszorg kan ongeluk wegnemen. ${ }^{80}$ In een samenleving waarin men elkaar vertrouwt, voelen mensen zich over het algemeen prettiger dan in een samenleving waarin wantrouwen overheerst. Behoort de kapitaalvennootschap nu tot het soort institutie dat mensen gelukkig makt?

Layard - een befaamde geluksonderzoeker - meent dat het nodig is dat een vennootschap het stakeholdermodel en niet

76. De betrokken regels zijn te vinden in art. 2:135-135b BW en par. 3.2.1-3.2.3 van de Corporate Governance Code.

77. Zie de inmiddels gecompliceerde $\mathrm{Wwft}$.

78. Zie hierover R. Layard, Can we be happier? Evidence and ethics, Londen: Pelican 2020, p. 187-192 en 227-232. Zie hierover ook het inspirerende boek van A.E. Clark, S. Fleche, R. Layard, N. Powdthavee \& G. Ward, The origins of happiness: The science of well-being over the life course, Princeton, NJ: Princeton University Press 2018 en het eerdere boek van R. Layard, Happiness: Lessons from a new science, Londen: Penguin Books 2011.

79. Zie hierover E. Klinenberg, Palaces for the people: How to build a more equal \& united society, Londen: The Bodley Head 2018.

80. Zie hierover R. Layard \& D.M. Clark, Thrive: The power of evidencebased psychological therapies, Londen: Allen Lane 2014. 


\section{Maandblad \\ Ondernemingsrecht}

het aandeelhoudersmodel volgt. ${ }^{81}$ Anders wordt zijns inziens alleen het geluk van de aandeelhouders bevorderd en dat is te beperkt, omdat volgens Layard 'the objective and raison d'être for any organization must be that it contributes to the happiness of the world'. ${ }^{82}$ In Nederland kennen we het stakeholdermodel al vele jaren. ${ }^{83}$ Niettemin bestaat er in Nederland onvrede over het functioneren van kapitaalvennootschappen.

Om hieraan iets te doen zouden we kunnen overwegen om het stakeholdermodel in de vennootschapswetgeving scherper uit te werken. ${ }^{84}$ Zo zouden prestatiegebonden beloningen die zijn gekoppeld aan de hoogte van een beurskoers verboden kunnen worden. ${ }^{85}$ Er zou een actierecht jegens de vennootschap voor betrokken niet-aandeelhouders in het leven geroepen kunnen worden, als deze bepaalde maatschappelijke belangen ernstig schaadt. ${ }^{86}$ Ook wordt momenteel door diverse auteurs voorgesteld om werknemers aandelen te geven. ${ }^{87}$ Denkbaar is dat in Boek 2 BW de eis tot maatschappelijke verantwoordelijkheid van de bestuurders van een vennootschap wordt neergelegd. ${ }^{88}$ Ik vind dat dit soort ideeën niet als utopisch afgewezen mogen worden. We moeten echt goed nadenken over de vraag wat voor soort samenleving we willen, en de moed hebben om goed doordachte ingrijpende veranderingen in de kapitaalvennootschap aan te brengen, zoals dat ook in de periode van de sociale onderneming vooral rond 1970 gebeurde.

Ook zou ik willen bepleiten om in Nederland - overigens in navolging van vele andere landen (Engeland, vele staten van de Verenigde Staten en Frankrijk) - een nieuwe rechtsvorm in te voeren, die zich bindt aan het bij uitsluiting bevorderen van duurzaamheid en niet aan het brede palet van belangen dat de huidige kapitaalvennootschappen dienen te behartigen. ${ }^{89}$ Dat brede palet biedt geen waarborg dat duurzaamheid door de desbetreffende onderneming voldoende wordt bevorderd. Ik

81. Layard \& Clark 2014, p. 123. Zie overigens ook D. Yosifon, Corporate friction: How corporate law impedes American progress and what to do about it, Cambridge: Cambridge University Press 2018. Deze auteur bepleit invoering van het stakeholdermodel in de Verenigde Staten. Hij hoopt dat hiervan het effect zal zijn 'that directors become informed about, think about and earnestly talk about the consequences of corporate conduct for multiple stakeholders', p. 178.

82. Layard \& Clark 2014, p. 122.

83. Zie de hiervoor genoemde Cancun-beschikking van de Hoge Raad en enkele andere genoemde arresten.

84. Zie voor ideeën hierover: P. Corning, The fair society and the pursuit of social justice, Chicago: University of Chicago Press 2011, p. 176-182.

85. Zie bijv. J.E. Stiglitz, Rewriting the rules of the European Economy. An agenda for growth and shared prosperity, Londen: W.W. Norton 2020, p. 136-138.

86. Zie Yosifon 2018, p. 179: 'A cause of action for non-shareholders to enforce the multistakeholder standard does not have to be easily or often deployed, but it must be there in some way, to make the system real.'

87. Zie bijv. Kees van Lede, in: K. van Lede \& J. Luyendijk, Pessimisme is voor losers: op de rand van een nieuwe tijd, Amsterdam: Balans 2020, p. 232-233. Zie ook R.B. Reich, The system: Who rigged it, how fix it, New York: Alfred A. Knopf 2020, p. 195.

88. Zie de voorstellen van de groep Winter, die binnenkort in Ondernemingsrecht worden gepubliceerd.

89. Zie over recente plannen voor zo'n nieuwe rechtsvorm de informatieve bijdrage van J.M. de Jongh, Naar een nieuwe variant van de BV?, Ondernemingsrecht 2018/121. heb de indruk dat jonge mensen grote waarde hechten aan duurzaamheid en dat ook graag naar buiten brengen. Als dat zo is, zou zo'n nieuwe vennootschapsvorm wel eens kunnen helpen het geluk van (jonge) mensen te bevorderen.

\section{Digitalisering}

Over de vierde fase hangt de slagschaduw van de vraag hoe het vennootschapsrecht dient om te gaan met digitalisering en wat de effecten ervan zullen zijn. Digitalisering is een game changer voor vrijwel alles wat we doen en dus naar alle waarschijnlijkheid ook voor het vennootschapsrecht. Ik verwacht dat de Nederlandse wetgever op termijn zal toestaan dat de besluitvorming in een vennootschap en het verrichten van vennootschappelijke rechtshandelingen, zoals omzetting en fusie, digitaal plaatsvinden..$^{90}$

Een voorbeeld van deze trend is de door de Europese Unie in augustus 2019 aangenomen richtlijn die de lidstaten verplicht om de oprichting van een BV digitaal te laten verlopen. ${ }^{91}$ Dus straks geen verplichte bezoekjes meer aan de notaris om een BV te kunnen oprichten, hoewel de Europese wetgever wel toestaat dat de oprichting van een BV bij notariële akte moet blijven plaatsvinden. De notariële procedure dient echter - zonder fysiek bezoek aan de notaris - digitaal te kunnen verlopen. Deze richtlijn bemoeilijkt het uitoefenen van de poortwachtersrol die de notaris onder de Wet ter voorkoming van witwassen en financieren van terrorisme (Wwft) dient te vervullen.

Vanaf 1 augustus 2021 (de datum van inwerkingtreding van de richtlijn in Nederland) kun je vanuit je Nederlandse of buitenlandse huis met een computer een Nederlandse BV oprichten. Maar je zou er ook voor kunnen kiezen om vanuit een knus Nederlands huis een digitale Bulgaarse BV op te richten. Door voor een Bulgaarse BV te kiezen zijn de mooie doelstellingen te ontgaan die de Nederlandse wetgever via ons vennootschapsrecht probeert te bereiken. Denk bijvoorbeeld aan het enquêterecht. Je kunt ook de 'strenge' Nederlandse poortwachters, zoals de notaris, ${ }^{92}$ ontlopen. Het is moeilijk te voorspellen wat de gevolgen van de richtlijn zullen zijn, maar digitalisering is een nieuw verschijnsel bij oprichting van een BV en zou tot gevolg kunnen hebben dat we naar een soort doehet-zelfvennootschapsrecht groeien.

Het veld waarop het Nederlandse vennootschapsrecht dient te worden toegepast, verandert nog verder, wanneer een andere richtlijn, de EU-Richtlijn 2019/2121 van 27 november 2019 over grensoverschrijdende omzetting, fusie en splitsing, op 31 januari 2023 in Nederlands recht is omgezet. In de toekomst zullen op grond van de nieuwe richtlijn ook grensover-

90. Vgl. de noodregelingen die digitale besluitvorming in de vennootschapssfeer versneld mogelijk maken in art. 10-22 van de wet van 22 april 2020, Stb. 2020, 124 (Tijdelijke wet COVID-19 Justitie en Veiligheid).

91. Richtlijn (EU) 2019/1151, inwerkingtreding in Nederland 1 augustus 2021.

92. Opmerking verdient dat lang niet alle EU-stelsels tussenkomst van de notaris voorschrijven voor de oprichting van een BV. 


\section{Maandblad}

schrijdende juridische fusies, splitsingen en omzettingen digitaal moeten kunnen verlopen.

Ik ga niet in op de ingewikkelde details van de nieuwe regelingen, maar duidelijk is dat het voor Nederlandse vennootschappen in ieder geval gemakkelijker wordt het Nederlandse recht te verlaten. Er is voorzien in een regeling voor bestrijding van fraude met grensoverschrijdende fusies, splitsingen en omzettingen. Het moet dan volgens de richtlijn gaan om gevallen waarin de fusie, splitsing of omzetting is opgezet voor onrechtmatige of frauduleuze doeleinden die leiden tot of gericht zijn op ontduiking of omzeiling van Unie- of nationaal recht, of voor criminele doeleinden. ${ }^{93}$ In dat soort gevallen mag de fusie, splitsing of omzetting geen doorgang vinden. De vraag is hoe effectief deze frauderegeling is. Mijns inziens kan de grensoverschrijdende omzetting in de toekomst worden gebruikt om van het Nederlandse enquêterecht af te komen. We weten niet of dit met behulp van de digitalisering werkelijk op grote schaal gaat gebeuren. De regeling in de richtlijn tot bestrijding van fraude is zwak. Hoe kan worden aangetoond dat het de bedoeling van een grensoverschrijdende omzetting is om nationaal recht te ontduiken? Dat lijkt mij niet eenvoudig. ${ }^{94}$

Is hiertegen iets te doen? Ik keer terug naar het hoofdthema van deze verhandeling: de verhouding tussen vennootschap en onderneming. We kennen in Nederland wetgeving die niet aan de vennootschap of de rechtspersoon, maar aan het begrip onderneming is gekoppeld. Voorbeelden hiervan zijn de WOR en de Handelsregisterwet. Zouden we er niet naar moeten streven om meer regels die nu deel uitmaken van het vennootschapsrecht van Boek $2 \mathrm{BW}$ vast te knopen aan het begrip onderneming? Ik denk hierbij aan het voor het Nederlandse vennootschapsrecht zo belangrijke enquêterecht. Zouden we niet een poging moeten doen om het vennootschapsrechtelijke enquêterecht van Boek $2 \mathrm{BW}$ aan te vullen met een ondernemingsrechtelijke variant die beter bestand is tegen digitale ontduikingstransacties? Zo komt de oude ondernemingsaap van prof. Romme uit 1946 uit de mouw: moeten we de onderneming niet wat meer bevrijden uit het vennootschapsrecht? Moeten we gaan streven naar een op de onderneming gebaseerd echt ondernemingsrecht? Prof. Sanders pleitte hiervoor al in $1971 . .^{95}$

93. Zie o.a. art. 86 quaterdecies lid 8 van de Richtlijn voor grensoverschrijdende omzetting. Voor grensoverschrijdende fusie en splitsing zijn in de richtlijn vergelijkbare bepalingen opgenomen.

94. Zie voor een vergelijkbare waarneming: J.N. Schutte-Veenstra \& M.A. Verburgh, De Richtlijn betreffende grensoverschrijdende omzetting, fusie en splitsing nader beschouwd, Ondernemingsrecht 2020, p. 212.

95. Vgl. overigens ook: P. Sanders, Op weg naar ondernemingsrecht, in: I.J. Dutilh e.a. (red.), Met eerbiedigende werking, Deventer: Kluwer 1971, p. 221-232. 